\title{
Forms and Boundaries of Art with Aesthetic Cognition in Art Therapy
}

\author{
Akila L. K. \\ School of Humanities and social sciences, Jain University, Bangalore \\ *Corresponding Author: akilamfa@yahoo.com
}

Copyright $@ 2014$ Horizon Research Publishing All rights reserved.

\begin{abstract}
The point of departure for this essay is two assumptions, the first is that art has no boundaries and brings out aesthetic cognition of all kinds of feelings and thoughts the second is that art as therapy is a brain training modality which is envisaged to frame brains. This brief report discusses the significance of art, art therapy, and the forms, which was developed from theory and research works of several fields (e.g., Art, Art therapy, Psychotherapy, Philosophy, religious and cultural fields etc.). A treatment of scholars, who have exerted on the brain, art, forms and boundaries, including Dissanayake, Coomaraswamy, Stella kramrisch, Shaun Mcniff, Judith Rubin, Zeki and others, is furnished to support the theoretical understanding. The main objective of this article is to provide (1) a viewpoint on art, forms and boundaries, to convey the difference between art piece, artwork and art, thereby; a sincere attempt is made to ascertain that art is knowledge of creating process, which has no forms or boundaries; and (2) to emphasize on art as therapy. Act of involving in the art process set off the subconscious mind towards greater awareness and realization, which is therapeutic by itself. Unfortunately, though we have copious evidence on the benefits of art, art therapy display predilection towards psychotherapeutic benefits. Art as therapy trains the mind to be stabilized and prevent the animal instinct or undesirable attitudes and problems that may otherwise arise. Thereby, suppressing the negative emotions; keeps the mind and body in control and avoids seeking external help.
\end{abstract}

Keywords Art, Art Therapy, Forms, Boundaries, Knowledge, Process, Creation, Feelings, Ancient Indian art

\section{Introduction}

Healing tools and modes have made enormous progress in the past several decades. The therapeutic benefits of art making have been studied in a variety of contexts and multiple modalities. Artworks are termed to produce aesthetically stimulating, comforting, and joyful environment. Art therapy has taken a great leap into the field of science. However, while reaping the benefits that art can provide, we have been ignorant to some extent regarding the perspectives of art and art as therapy. These observations arise few questions: What is art? What are the forms and boundaries of art? Why do we need art therapeutic modules? How exactly art can be utilized as a brain training module? In the backdrop of these doubts, believing that art as therapy trains the brain to stay stable and prevent the animal instinct or undesirable attitudes and problems that may otherwise arise; this article makes a sincere and humble effort to rekindle the concept of art as therapy.

With the increased interest, research, and practices art therapy has gained its roots in Singapore, France, Slovac Republic, Canada, Ireland, Australia, the UK, Greece, Italy, the Netherlands, South Korea, Belgium, New Zealand, Hungary, Honduras, the United States, South Africa, Germany, Peru, Bulgaria, Indonesia, Jamaica, Chile, Hong Kong, and China ${ }^{1}$. Regrettably art therapy is still awaiting an entrance in South East Asia.

The main objective of this article is to provide (1) a viewpoint on art, forms and boundaries, to convey the difference between art piece, artwork and art, thereby; a sincere attempt is made to ascertain that art is knowledge of creating process, which has no forms or boundaries; and (2) to emphasize on art as therapy.

Understanding art as therapy requires an in-depth analysis of the concept of art and its uses. First, the concept of art, its form and boundaries are discussed to provide the difference between art piece, artwork and art itself. Second, direct benefits of art making are summarized to unveil the usefulness of free art sessions for patients, staff, medical students, and scientists and to the field of neuroscience. Third, the importance of art as therapy is discussed. The concern that art is being observed as parasitic, in the treatment modalities is addressed. Fourth, the need for a new module to enhance 'art as therapy' concept is discussed. In the end, the article is concluded by evincing a need for novel module of art as therapy.

\section{Notion of Art}

\footnotetext{
${ }^{1} \mathrm{http}: / /$ arttherapywithoutborders.wordpress.com/
} 
Arts comprise several components, such as Style, Content, Form, Media, Technique and several such things, that creates literature, poetry, music, visual arts, sculpture, music, dance, the theatre, and the cinema, are to mention only a few of the forms, though not all inclusive of the arts. Such abundant display of knowledge which brings out multiple forms and enumerable components has no boundaries or a comprehensive form by itself. Throughout the article wherever forms and boundaries are mentioned to reflect the content of the artwork, should not be mistaken as forms and boundaries of art.

While making art one will learn to create, improve aesthetic representation and depicting transcendental forms. The more one works more one learns; hence, making of art is a knowledge-creating process. The knowledge thus gained assists the creating process; hence the art is the knowledge of creating-process. Put together we can derive that 'Making of art' is a knowledge creating process, and 'the art' is the knowledge of creating process. Knowledge has no conditions or boundaries, we cannot create it, but it always exists; art is the insight which intelligence can only judge but cannot attain ${ }^{2}$.

In simpler terms, art can be divided into three segments:

a. Knowledge of art which helps us think in an artistic way,

b. The process of art which helps us to create, and

c. Creation of art; the finished product (artworks and artifacts)

Perception is the knowledge which creates what is conceptualized and the conceptualization is the consequences of perception to create: this phenomenon expands the knowledge of art. Added to the knowledge of art, it is observed that new affiliations, new forms, new productions and new materials are being built up every day making it vast and never ending process. Thereby cultivating, coexisting activities that are acquired appreciated and adopted by and for artists and art lovers, from the time of ancient historical traces. We cannot thus define a form or boundary to this everlasting, ever enchanted art.

Art is the source of free flowing thoughts, which are unique and spontaneous. They embody expression and realization of self, new ideas and methods. Art is not self-referring monument, but an experience for an artist. It is an evidence for archaeologists because it supports chronology, expression for psychologist because it signifies personality, it is the documentation for historian because it represents heirloom. It is a collection for art lover simply for the love of art and performance for a dancer or actor, and so on. Equally important is Picasso's statement that "the urge to destroy is also a creative urge", though it sounds like an oxymoron, on deeper contemplation rings true. Therefore, art is that knowledge, which is all-pervading in the form of an act, whatever it may be.

According to some cognitivists, art was equal to the

\footnotetext{
${ }^{2}$ Ananda K. Coomaraswamy, The aims of Indian art, Source: Studies in Comparative Religion, Vol. 9, No. 1. (Winter, 1975). World Wisdom, Inc.
}

beauty - something to provide delight to our senses ${ }^{3}$. Beauty that comprised fitness, clarity, harmony and radiance were the standards proposed by the artists and philosophers. Definition of art was changed to truth, order, unity in variety, and significant form in Nineteenth- and twentieth-century. Hence deriving a definition of art failed its purpose ${ }^{4}$. Philosophers are providing proposals for a definition of art, but a debate is still on among them ${ }^{5}$.

\subsection{Forms and Boundaries of Art}

Children have abundant creativity, since they are unaware of any boundaries, they experiment with colors that are pleasant, enjoyable, and pleasing to the eye and perceive everything as a subject of learning and understanding, with each small thing considered as a sensational one, without any prejudice $^{6}$. Not only does each of these factors, along with innocence and ignorance directly contribute to their wellness, but also for their creativity ${ }^{7}$. Whereas, whether it is creative work or any other task, adults try to analyze the work given to them, they would try to combine their logical, reasoning, and problem solving skills, to produce the best result and try to make their presentation aesthetically and analytically fool proof, thus, suppressing divergent thinking and creativity that is part of a child's life ${ }^{8}$. Along these lines, the logic, reasoning, and problem solving skills are envisaged as the boundaries, which, according to Geist Richard "externally imposed boundaries impede rather than facilitate rekindled growth".

Along these lines, as children grow up they confront externally imposed boundaries, which tend to limit their creativity. If these limits are obliterated from the mind, never-ending visions of art start gushing forth. As precisely told by Giorgio De Chirico, "Perhaps to become truly immortal, a work of art must escape all human limits: logic and common sense will only interfere. But once these barriers are broken, it will enter the realms of the childhood visions and dreams" $"$. By stating that "a work of art must escape all human limits", Giorgio emphasizes that work of art should always be combined with other segments like conception and perception with unlimited and abundant possibilities.

\footnotetext{
${ }^{3}$ Dissanayake, e. (2008). The arts after Darwin: Does art have an origin and adaptive function? In K. Zijlmans \& W. van Damme (eds.), World art studies: Exploring concepts and approaches (pp. 241-263). Amsterdam: Valiz.

${ }^{4}$ Dissanayake, e. (2003). "Core of Art: Making Special." Journal of the Canadian Association of Curriculum Studies, volume1, number 2.

5 Adajian, Thomas, "The Definition of Art", The Stanford Encyclopedia of Philosophy (winter, 2012 Edition), Edward N. Zalta (ed.), URL = $<$ http://plato.stanford.edu/archives/win2012/entries/art-definition/>.

http://psychcentral.com/blog/archives/2011/01/13/5-ideas-for-cultivating-a -sense-of-wonder/

De Bono, Edward, Serious creativity, The journal for quality and participation; Sep 1995; 18, 5; ABI/INFORM Global pg. 12-18

Zabelina., Robinson, Child's Play: Facilitating the Originality of Creative Output by a Priming Manipulation, Psychology of Aesthetics, Creativity, and the Arts, 2010, Vol. 4, No. 1, 57-65

${ }^{9}$ Geist, Richard, Empathy, connectedness and the evolution of boundaries in self-psychological treatment, International Journal of Psychoanalytic Self Psychology, 2009, 4: 165-180

${ }^{10} \mathrm{http} / / / \mathrm{www}$.theartstory.org/artist-de-chirico-giorgio.htm
} 
When one tries to prove that art has a boundary (e.g. Paper's edge) and forms (what they create), they are only citing to a composition of artwork and not to art as a whole. We acquiesce with Coomaraswamy ${ }^{11}$ that suppose a person after exerting all his senses into finishing an artwork does he stand devoid of art within him? If so, what happens to the art which is however within that individual? So, which form did he draw? What boundaries did he encounter? The verity is that he barely wound up making an artwork oblivious of form and boundaries. Art can give form and explore boundaries of an artwork, but to explore boundaries of art itself is quite an indeterminate and weird idea. A Swedish American sculptor Claes Oldenberg explains the unattainable and unrestrained boundaries of art as "If I didn't think what I was doing had something to do with enlarging the boundaries of art, I wouldn't go on doing it."

\subsection{Direct Benefits of Art}

Psychology and art therapy might have been in use to heal from thousands of years, for instance, in the 7th century hinting on psychological treatments and awareness that were existing Vaghabhatta in his Ashtanga Hridaya narrates as "Salutations to The Unique and Rare Physician, who has destroyed, without any residue all the diseases like Raga (lust, anger, greed, arrogance, jealousy, selfishness, ego), which are constantly associated with the body, which is spread all over the body, giving rise to disease, delusion and restlessness ${ }^{12}$ ". Concurrently almost at the same period, The Chitrasutra of the Vishnudharmottara Purana, in his discourse on Indian painting prescribes art is a form of emotional communication and a healing process, he says: "Painting cleanses the mind and curbs anxiety, augments future good, causes the greatest delight, kills the evils of bad dreams and pleases the household deity"[33]. These ancient scholars, though have specified these therapies did not explicate the details as the fields were out of the scope of their literature purview; however, they have left behind remarkable evidence on these therapies. Therefore, it is apparent that Indians worked with the awareness of art's therapeutic benefits, which can be adverted to as an established concept of art therapy. Kramrisch proclaims that Chitrakara often admits that the knowledge of Vishnudharmothara is a mere transference of the knowledge he pursued from Indian lineage repeated and compiled from older sources [does not mention whether the older source was in the form of text/ verbatim/training[36]. A substantial research remains open for any further literature review and literature search for more details on these supposedly lost therapies.

It is agreed that healing process gets hampered with clinical interventions, especially in children; on the contrary, art as a non-verbal method is considerably helpful [46]. The

\footnotetext{
11 Coomaraswamy, why exhibit works of art? Studies in comparative religion, Vol 5, No. 3 (summer, 1971). World wisdom, Inc.

http://www.learningayurveda.com/2012/08/31/ashtanga-hrudaya-sutra-stha na-chapter-1-basic-principles-of-ayurveda/
}

atmosphere is utmost important. Art studio is more welcoming and enables children to believe that they can carry through something over there, while the clinical environment is fearful and fretful [39]. Staricoff ${ }^{13}$ [52] in her exhaustive research review summarizes her findings as, commitments with local artists and museums can exhibit a substantial improvement in medical students. Foreword by Peter Hewitt acknowledges that artists are well aware regarding the positive impact and benefits of their works in healthcare centers. Hence art, studio atmosphere and artists can be major components in art therapy and health care.

Art of medicine can be enriched with responsiveness, consciousness, and thoughtfulness by combining art based activity in medical students ${ }^{14}$. Visualizing the art works can improve observation and understanding-skills of students during medical training ${ }^{15}$. Art making, aesthetic improvements and installations can be worthwhile during treatment as they reduce the anxiety, provides a positive response to the treatment and speeds up the recovery, thereby reducing a prolonged treatment and increased expenses ${ }^{16}$. All these research reports show that art directly benefits the patient, staff, medical students and families. Art is vital for effective medical training and treatment.

Neuroscience has shown amazing advancements using art, without relying on theoretical explanations or interpretation, e.g., fMRI (functional magnetic resonance imaging) observes direct variations in the brain's network during visualization ${ }^{17}$. Observing or producing visual art reduces the distress by opting positive distraction from negative feelings and thoughts thereby promoting health benefits ${ }^{18}$. Zeki ${ }^{19}$ interprets that creative process helps in cognitive development; creative manifestation leads to self-awareness and improves brain function capacities. Many scientists explore the use of art; such scientists illustrate and publish more advanced, highly cited research than the average scientists who are not involved in visual $\operatorname{arts}^{20}$. Hence, art making not only plays its role in healing but also places itself in the intellectual science camp.

This article is intended not to go against art psychotherapy or psychotherapy, but unfortunately, though we have copious evidence on the direct benefits of art, art therapy

13 Staricoff research report. http://www.artsandhealth.ie/wp-content/uploads/2011/08/AHReview-of-M edical-Literature1.pdf

${ }^{14}$ Jo Marie Reilly; Jeffrey Ring; Linda Duke. Visual Thinking Strategies: A New Role for Art in Medical Education, Fam Med 2005; 37(4): 250-2.

15 Jasani SK, Saks NS. Utilizing visual art to enhance the clinical observation skills of medical students. Med Teach. 2013 Jul;35(7):e1327-31

${ }_{16}$ Studies show that incorporating the arts can save money, improve the patient experience - and do a lot more. http://www.ucira.ucsb.edu/why-we-need-the-arts-in-medicine/

${ }^{17}$ Edward A. Vesse, G. Gabrielle Starr, and Nava Rubin, Art reaches within: aesthetic experience, the self and the default mode network, Front Neurosci. 2013; 7: 258.

${ }_{18}$ Lankston., Cusack., Fremantle., Isles, Visual art in hospitals: case studies and review of the evidence, J R Soc Med. Dec 1, 2010; 103(12): 490-499

${ }_{19}$ Semir Zeki, a former professor of neurobiology at the University College, London published an article, "Artistic Creativity and the Brain," in Science Magazine, in July 2001.

${ }^{20}$ Daniel Gurnon, Julian Voss-Andreae, and Jacob Stanley, Integrating Art and Science in Undergraduate Education, PLoS Biol. Feb 2013; 11(2): e1001491. 
displays predilection towards psychotherapeutic benefits. The concern is in the present situation of art therapy, where art is observed as parasitic on psychotherapy since it believes nothing can be achieved without verbal communication. On taking the risk of compromising with psychotherapy, this article questions whether we have lost the concept of "Art as therapy"? Have we sacrificed the essential values, viewpoints and integrity of art in the process of reconciling art and psychology?

The benefits of art have been discussed throughout the art history, philosophy, psychology, and anthropology literatures. In Dissanayake's point of view people who were involved in art survived better than those who did not, culturally primitives use to pass on the morals and information, and psychologically they use to relieve from the anxieties of uncertain life (Dissanayake 1992a as cited in [34]). Kaplan argues that by enabling language development, creativity, problem solving skills, self-esteem, and mental reparation visual art can support our well-being [34].

\section{Art Therapy}

Art therapy has emerged as a prevalent therapeutic model and has a long history of several decades. Art is a powerful tool in communication that can be used to understand emotions, stress and innate complexities of people. The ability to reduce anxiety, resolve life's struggle and enhance life without any age bar has elevated art into the realm of therapeutic forms, be it spiritual healing, medications, play therapy, neuroscience, etc., [39] getting involved with the practice of art making improves observation, hand and eye coordination, perception and brings in relaxation and reparation. Overall well-being is observed due to the art's nature of self-soothing (p353). Like Shaun McNiff[41] denotes that art is the medicinal source, the therapist is just a teacher and an observer of the beneficial outcome, this self-soothing behavior and medicinal properties of art is what is addressed as art as therapy, whether it is art making or art appreciation.

In art as therapy it becomes difficult to provide dynamic therapeutic benefits as the client needs to have a rudimentary skill of making art[44], similarly, clients without rudimentary skills of art making may face difficulty in producing their mental discrepancies in art psychotherapy [44], and nothing happens without discourse.

There can be an attempt made to provide a middle path in this understanding by developing an art instruction module, where technical skills are limited to certain minimal drawings (few basic drawings of real and imaginary world). The simple drawings may not attempt to improve the aesthetic qualities of the analysand as in art as therapy. At the same time will not let down the analysand, to be naïve in making his wishful representations. However crude, the drawings are, once clients start representing their feelings both schools of art therapy can accommodate the client into their therapy. Nevertheless, it is assumed that, crude drawings are enough to motivate them for more aesthetic pleasures and is capable of producing healing properties, as Zeki[57] describes that art submits itself and enacts as a resemblance and an extension of the visual brain.

Art work and observations are, may be linked to comfortable justifications made by clients when we seek verbal explanation. Comfortable explanations proceed with ignorance, insecurity, uncertainty, cover ups and disparity that a client might possess or poses[53]. Science fails to assess why a person depicts artworks that is a false positive response, when the situation of representations controls his mood. Moreover, it is the human tendency to oppose the personality analysis whenever they feel discomfort, rather than depicting the primary mood disorder, they prefer to depict unaccomplished desires, hoping for mercy and/or fulfillment. This leads to wrong assertion. Very first problem in analyzing an artwork is, to know whether the content is logical or natural whereas these are the results of intellect and imaginations respectively[44]. More complicated is a combination of these two which is challenging to bifurcate. Intellect or imaginations both may contain real or false images, hence it is problematic to understand and extract problem of the analysand, and to recognize what is the disorder or whether there is a need for therapy.

Kaplan[34] points out that Miller, an art therapist, conducted insight-oriented art psychotherapy to mentally ill adults, which did not produce any positive result, thus she offered them loosely structured art activity which was more satisfying and rehabilitative. Further, Kaplan states that the beneficial effects observed were outside the psychotherapy background and solely depended on art making.

When art psychotherapy strongly believes in discourse, it fails to enlarge upon what is already known and established in psychotherapy and keeps one in confusion, regarding what art can provide more than the benefits of retrieving images for clinical psychology purpose. Not necessarily by means of art psychotherapy, but treatment would any way happen through psychotherapy, as art psychotherapy strongly believes in discourse and its attributes.

\subsection{Art, Feelings and Emotions}

Art brings out aesthetic cognition of all kinds of feelings and thoughts. The simple reason that art is appreciated in all walks of human life and many of them being considered as divine to seek positive drive suggests that there is something that art can offer more than depicting finite experiences and few emotions.

Lehrer Keith[38] states, man makes art by making distinctions and it is a process of creating order from chaos. To begin with, the selection of material itself is a chaotic process and next comes the chaotic battle between sovereignty versus structure during the process of making art [43]. So do we mean art is creating forms from chaos? Making distinctions, selection of material and media, or jumbling with our potentials are basically logic. Logic is relevant in a vast number of theories, merely one can restrict 
the appropriate use of logic [or consider it as chaotic], as it is basic for any kind of knowledge ${ }^{21}$. A person who does not have rudimentary knowledge of art making fails to produce anything as he is 'bound to judgement which kills creativity and thinks of patterns instead of setting it up ${ }^{22}$, maybe, it is a chaotic process to him, creativity but for an artist is routinely an easier task ${ }^{23}$. What is the obvious connection between logic and chaos? Goertzel Ben[20] puts it as the sensitive dependence to initial conditions as the key concepts for chaos, hence not knowing the process of art, puts a naïve person into chaos [even before art psychotherapy is carried] whereas, for an artist logic flows endlessly because of his existing structural predictability. Since art is certain kind of knowledge, using our knowledge should not be chaotic process as Solso[51] says knowledge is methodically arranged in the brain to help in understanding of art and every other certainty. A naïve client might have the chaotic disorder, but may possess a certain kind of different talent too; most of them will be more creative in some other field according to their own traits.

According to one's cognitive and personality traits, people tend to pick skills of their own choice. Personal qualities like:

"A valuing of creativity, originality, independence, risk-taking, the ability to redefine problems, energy, curiosity, attraction to complexity, artistry, open-mindedness, a desire to have some time alone, perceptiveness, concentration, humor, the ability to regress and the possession of childlike qualities. These personality traits are linked to thinking styles, which involve: visualization, imagination, experimentation, analogical/metaphorical thinking, logical thinking, predicting outcomes or consequences, analysis, synthesis and evaluation"[55]. These personality developments are a combination of thoughts, feelings and experience logically analyzed and assumed by people, hence the number of possibilities on hand can't be considered as chaotic always. Instead, an art therapist identifies the forms of chaotic and controlled emotions within the frame of a client's artwork.

Bruce says "every decision that the artist makes serves to structure the chaos of possibilities......" [43], what we can extract from Bruce's statement is even before the artist starts his work, as soon as he selects canvas and other materials chaos of choices and options are dissolved and the forms are created from the chaos of infinite potentials but not from chaos itself. Bruce in his own words say art making is not always chaotic - "I agree that making art is good; however, it is not always" [43].

At length art has changed in its media, in its forms, in its perspective but had never faced elimination. This creative art cannot be conveyed by any language[15], it is visual but

\footnotetext{
21 Kowalski, Robert, The limitations of logic, http://www.doc.ic.ac.uk/ rak/papers/limitations\%20of\%20logic.pdf ${ }_{22}$ De Bono, Edward, Serious creativity, The journal for quality and participation; Sep 1995; 18, 5; ABI/INFORM Global pg. 12-18

${ }^{23}$ Simon Lacey., Henrik Hagtvedt., Vanessa M. Patrick., Amy Anderson., Randall Stilla., Gopikrishna Deshpande., Xiaoping Hu., João R. Sato., Srinivas Reddy., and K. Sathian. Art for reward's sake: Visual art recruits the ventral striatum. Neuroimage. Mar 1, 2011; 55(1): 420-433.
}

mute, it is vigorous but still. The language of art is more open, descriptive, impressive, curative, and attentive. Art, though being mute breaks the verbal barrier without a word!

Besides, breaking these communication barriers art provides a bridge between the conscious, and inaccessible unconscious hemispheres of the brain, through which the deepest of unrealized agony, grief, and chaos and the unattained urge of pleasures, along with the perceived satisfaction, and joys can be depicted by means of art materials. Incidentally Rubin points out that "While it was necessary for Dorothy to loosen up with a free painting experience in order to look at her feared fantasies, Randy needed to get himself together in order to depict his wishful ones"[47], this is an enduring clarification that suggests art is not just about creating form from chaos. It heals disorders, makes one stronger and relaxes mind and body. Art is a meditation for anyone who subscribe to it, not only for the disordered.

\subsection{Crazy Artists and Suicides of Psychologists}

It appears to be too simple to say that art as therapy is therapy by itself, a self-healing process, or an auto reparative tool. Often the concept strikes to get to its point. For e.g., Regarding addiction and art, the disgraceful act of being addicted can be resolved by involving in art activities [48] these, points get blurred as we question what about those crazy drug addict artists who could not cure themselves in the procedure of creating artwork? Does art have self-healing capacities? Can a common man win through art where world renowned artists failed? These questions may make us turn back to psychology, but Tori DeAngelis ${ }^{24}$ says, according to several studies conducted psychologists are subjected to threats of suicidal ideation than the overall population.

An astonishing percentage as high as 40 to 60 percent of psychologists faced disruption due to work load, anxiety and depression was reported by A 2009 APA survey, such instances affect clients and psychologists are insufficiently prepared to deal with distressed colleagues which comes as a blow in the discipline of psychology ${ }^{25}$. Mausner and Steppacher ${ }^{26}$, conducted a study, where weirdly a doubtful, anxious and unsuccessful career were major reasons of psychologists committing suicide.

With the Initial impact of being unsuccessful many people starts planning to die and psychologists are not left behind. Swiss psychiatrist Hermann Rorschach (1884-1922), whose ink blot test is obviously popular could not wait to see his work propel, with all the drawback of financial blockage, he reduced his inkblot prints to 10 numbers, the failure of his publication made him to die committing suicide. [49]. Likewise, we have witnessed Suicides of "noted psychologists Michael J. Mahoney, PhD, in 2006, and

\footnotetext{
24 https://www.apa.org/monitor/2011/11/suicide.aspx

25 https://www.apa.org/monitor/2011/11/suicide.aspx

26 J. S. Mausner and R. C. Steppacher, Suicide in professionals: A study of male and female psychologists,

http://aje.oxfordjournals.org/content/98/6/436
} 
Lawrence Kohlberg, $\mathrm{PhD}$, in $1987^{27}$ ".

As an example of addiction Freud encouraged cocaine and he himself was a cocaine user, his biographer Ernst Jones says Freud use to smoke up to twenty cigars a day in the process he developed cancer and begged his physicians to down him $^{28}$.

Further, what about the psychologists who suicide one after the other.... Why couldn't they heal themselves as similar to artists who were not cured by their art at all? Did those artists with the process of art, live long being addicted rather than committing suicide?

Art definitely has something to present at least the urge to live. Dr Staricoff quotes Swedish research showing that "engagement with the arts is associated with longer life expectancy" [52]. What art can afford us and what we can obtain will remain unrevealed till we get pitched to this marvelous concept of art. For an artist habitually and explicitly reward processing is instantiated which increases positive reinforcement and influence the brain neural processing ${ }^{29}$. The art instinct therefore has been eternally planted in the heart of man. Art provokes happiness when one lives merrily, and when one is in pain, yet it provokes the happiness by removing the deep rooted grief of the soul, hence it is impossible to destroy the art and appreciation that are imbibed in a man [10].

Let us not be too very confident on all sorts of artworks. More negative content in the works of art might signify or induce imbalances in the artist himself, for e.g., look at Henri de Toulouse-Lautrec's art works, many of it contains negative emotions like sad and harsh bohemians life, though cabarets look like merry time art works, it depicted the cheap and sympathetic life, and in Van Gogh's paintings artworks looks whipped up with obscure emotions and tumult ${ }^{30}$. Hence, repeatedly depicting negativity, depressed and addicted artists were born.

All these creative people and psychologists were aware of their situations; an artist who is an addict or a psychologist with problems needs to confer other therapists or reform themselves to a more positive attitude. They simply didn't bother about the consequences and were just not ready to come out of the problem. It cannot be generalized to everyone in the field. Hence a positive thinking is required to enrich the theory of art as therapy.

Without readiness, and self-preparedness any therapy would fail in producing beneficial results. What seems most important to remember is that the art made in therapy is not only a source of information for the therapist; it is also a mirror for the youngster, as Edith Kramer once wrote, "Paintings are valuable not so much because they can tell the adult something about the child, but also because the very act of creating helps the child to learn something new about

\footnotetext{
${ }^{27} \mathrm{http}: / /$ www.apa.org/monitor/2011/11/suicide.aspx

$28 \mathrm{http} / / /$ psychology.about.com/od/sigmundfreud/tp/facts-about-freud.htm

29 Simon Lacey., Henrik Hagtvedt., Vanessa M. Patrick., Amy Anderson., Randall Stilla., Gopikrishna Deshpande., Xiaoping Hu., João R. Sato., Srinivas Reddy., and K. Sathian. Art for reward's sake: Visual art recruits the ventral striatum. Neuroimage. Mar 1, 2011; 55(1): 420-433.

${ }^{30} \mathrm{http}: /$ www.toptenz.net/top-10-tortured-artists.php
}

himself. This process of self-discovery and self-acceptance through art is the core of art therapy" [47]. Unclear and blur mental images become clear and meaningful during art therapy course[47] and this brain game is not possible, without client's willingness and enthusiasm which is raised by the foreseen pleasure of creating art itself. So Shaun McNiff[41], rightly said art is the tool through which a therapist guides the client to heal, and the medicine is art again.

\subsection{Ancient Indian Art: A Therapeutic Model}

Cultures are the pillars of aesthetic appreciation; lineages of our societies in particular have nurtured the art and transmitted it from generation to generation [19].Seeking positive energy among religious or cultural imagery and implications between the warmth of temple's four walls, sculptures on the pillars and walls and the idol that is inside the sanctum represents the artistic, mental imagery and reparative process. In India, art is considered divine; culture and paintings were so entangled that it was hard to distinguish them. The notion that in ancient India every cultured man had drawing board and paint materials at home [36] is enough to ascertain the perceived bond between culture and art.

Hindu view of art was not for leisure, not to while away hours, or not to flee away from life's turmoil. The outstanding advantage of art was to advance into souls ambitions, to stir up enchantment, to perceive goals and to attain self-realization[29] like Scoffham ${ }^{31}$ says "Rich experiences can promote brain growth while sensory deprivation can inhibit it. Furthermore, because the brain is actually physically changed by the circumstances in which it operates, we can mold it to our needs". The same concept was addressed and instrumented in Indian art. Indians were well aware of the consequences that negative emotions depicted in a painting can bring upon, hence paintings of the supernatural and dreadful sides of the life were, supposed to be placed in temples or in halls meant for royal audiences and not in the houses as detailed in Chitrakara's Vishnudharmothara [17, 36]. Hence, during art therapy sessions paintings with negative content on the walls or any part of the hall, may influence a person to depict even a marginally threatening aspect of his life to be more aggressive. Ancient Indians had cognizance of the benefits as well as the psychological destructive qualities of the painting. Chitrakara at one stage tells painting in a house brings upon positive psychological benefits [17, 33], and on the other hand, he says an artist should not keep his work in his own house [there is no other clarifications given of disadvantages that might arise by doing so] [17, 36].

Though Indian art is recognized as religious art, Bhattacharyya[3] suggests that there were numerous "Figures of women, widows and prostitutes, dwarfs, generals, foot-soldiers, archers and wrestlers are some of the motives

\footnotetext{
${ }^{31} \mathrm{http} / / /$ www.leeds.ac.uk/educol/documents/156298.htm
} 
prescribed. Besides these, were the natural objects like mountains, sea, forest, water, city and villages, markets, drinking places battlefields, burning ground, roads, dawn and night, moon shining and rain falling and so on". Many of the objects were forbidden to be kept in the houses. If rock hard sculptures could be deformed and destroyed by invaders in the past, it is easier to imagine what would have happened to the paintings that were kept in chitrashala, temples, public halls and palaces before Mughals invasion. There is a possibility of losing major contribution of art works which would have otherwise thrown light on the grounds of Indian art.

Researches like mindfulness-based art therapy (MBAT) while reducing distress and enhancing the significance of life in cancer patients highlights the importance of meditation as well ${ }^{32}$. In India it was advised, any artist to meditate deeply before creating art works, after following this discipline they use to develop ultimate concentration[17], stability and calmness are the result of meditation[36].

Many might find Mandala art therapy calming and relaxing, "mandala" is a word from Indian language which means "circle". Nature of mandala is suggested by lotus shape[36], they are found in many forms across India eg., Rangoli (Patterns drawn in the front yard of the house), yantras (divine mandalas either framed and worshiped or inserted in charms and amulets), the dance halls, king's court, public halls are were decorated with mandalas (also indicates the center of the hall). Temples were built according to mandala, cosmic force was described through and mounted upon them[17]. As we can see sanskrit words inscribed in many art works outside the nation, Buddhist ritual, education and assimilation must have passed this art to many other countries $^{33}$.

Indian art was not intended to simply depict the nature; memory pictures, power of visualization and imaginations were the main components that worked towards the goal. The imitation of nature was considered to be opposing imagination and was not encouraged as a work of $\operatorname{art}^{34}$. The nature and function of art has to propose a positive impact on souls and not the inferiority of materialistic reality, hence, Plato decided to eliminate realistic artists from his republic whose art is "a reflection of a reflection, a copy of a copy, a shadow of a shadow ${ }^{35}$.A perception that measure and chooses the component and content of artwork must benefit the society and reject the destructive qualities. This inner intuition provokes an effect of aesthetic state which is known as Chamatkara, to attain this one need to have an unbiased

\footnotetext{
${ }^{32}$ Monti, Peterson, Kunkel, Hauck, Pequignot, Rhodes and Brainard, A randomized, controlled trial of mindfulness-based art therapy (MBAT) for women with cancer, Psycho-Oncology 15: 363-373 (2006)

${ }_{33}$ Dine, Susan, 2012, Sanskrit Beyond Text: The Use of Bonji (Siddham) in Mandala and Other Imagery in Ancient and Medieval Japan, University of Washington.

https://digital.lib.washington.edu/researchworks/bitstream/handle/1773/20 584/Dine_washington_0250O_10572.pdf? sequence $=1$

34 Ananda K. Coomaraswamy, The Aims of Indian Art, Studies in Comparative Religion, Vol. 9, No. 1. (Winter, 1975). World Wisdom, Inc. Www.studiesincomparativereligion.com.

35 Philip Sherrard, Art and Originality, Source: Studies in Comparative Religion, Vol. 14, Nos. 3 \& 4. (Summer-Autumn, 1980). World Wisdom, Inc.
}

data, sensory and mental image, knowledge of combining these, and sub-conscious or conscious mental data [9]. Finally, an object drawing may improve or exhibit the representational skills of the external world, this derives no other inner meaning of an artist's intuition nor it would make an impact on the observer's mind frame.

While accepting psychology for its therapeutic properties for healing the negative content of the mind, we may also have to consider the deep rooted feelings and emotions such as sex, fear, anger, hatred, etc., these are inseparable root-emotions and prevailing characteristics of human beings [9]. These emotions cannot and should not be uprooted as these are inescapable and universal (p80), nor should be intervened without reason; at the same time, it should be kept at bay to avoid arousal of the animal instinct. So what can lead to this magic? According to Indian art-critics, the job of the artist and the art product is to pull the observer into a unique aesthetic state where strange personalities of the observer could be abridged[9]. By doing so the psychological problems that may arise in the future is curtailed, thus, considered an essential benefit of art endowed to the society. Psychology tries to cure after analyzing the existing problem but Indian art used to suppress the problem that may arise. Hence art was not only meant to heal self, but also to impose a positive feeling and environment which was duly benefited by the society.

When Westerners inclined to western psychotherapy Indians persuaded with mental training[2], apparently considering prevention is better than cure and identifying consonance that may be attained through delightful aesthetic state and perceiver's personality[8]. Religious art was used to uphold principles in education, to pass on facts and figures, to induce positive emotions and healing. Images were used to kindle the wishes and thirsts[44], as it can bring back one from laid-back attitude. Basically, with modernization, these healing benefits of cultural or religious art concepts have gradually vanished.

\section{Discussion}

This article discussed about art, form, and boundaries, presented information about the efficacy and need of art and art as therapy. In summary, art is a form of knowledge applied in the creating process, which is neither tangible nor contains a special shape or bound. Apparently what is created, developed or performed is considered as art work, art piece or art form, which is obvious to comprise forms and boundaries. Art can be utilized as a primary aspect of correcting, training, shaping and healing an individual's mind. Given an opportunity, a person's brain can be aligned to the reparative representations of art process. Such representations involve the role of acquired skills that make a shift from low self-esteem, oblivion, and restrictions. Though particularly ancient Indian art has been considered in this article, more work on cultural arts of the world need to be speculated as Dissanayake suggests "all cultures have 
devised ways of dealing with their members' vital concerns and, as I have shown, the arts are integral parts of this armamentarium" $" 36$.

Art made under more conscious control of emotions can induce positive feelings in an observer. Art of any form, be it literature, dance, movie, etc., trains the brain of the people either positively or negatively, as it is the content which benefits or harms the society.

Of late, reference to art as therapy has been rare and rarer yet is the attribution of its individual benefits. Glimpses on classic features of art as a brain training modality has been provided in this article. Thus, this more refined and advanced form of mentoring minds calls for an immediate attention. Kramer's argument "art therapy's greatest power resides in using art as therapy" [34] and Reynolds \& Kamphaus's [46] incorrect emphasis of art psychotherapy upon psychological foundations needs to be re-examined emphasizing direct benefits of art.

This work provided a partial support for the pre-experimental theory of art as a training modality and requires an extensive research to be directed in order to conceptualize the same. Encouraging clients to make artworks with positive content might improve their positive thinking and wipe out or decrease the negative emotions; these positive contents train the brain to visualize the positive side of their life. Positive and negative emotions in human life ever exist, more they learn to enjoy the positive feelings, negative contents will become less bothering.

More theoretical interpretations of these fields need to be examined to produce a concrete account of brain training. Consideration of these specific theories and subject areas is meant to develop incrementally a new module of the art as therapy.

\section{REFERENCES}

[1] Adajian, Thomas, "The Definition of Art", The Stanford Encyclopedia of Philosophy (winter 2012 Edition), Edward N. Zalta (ed.), URL =

$<$ http://plato.stanford.edu/archives/win2012/entries/art-defini tion/>.

[2] Akhilanada, Swami, 1952, Mental health and hindu psychology, Jarrold and Sons Limited, Norwich

[3] Bhattacharyya, Tarapada. 1947, The Canons Of Indian Art or A study on Vastuvidya, Inland Printing, Calcutta, India

[4] Borev, (1985), Aesthetic: A text book, USSR, Progress Publishers.

[5] Coomaraswamy, Ananda K. The Aims of Indian Art. Source: Studies in Comparative Religion, Vol. 9, No. 1. (Winter, 1975). World Wisdom, Inc.

\footnotetext{
${ }^{36}$ Dissanayake, e. (2008). The arts after Darwin: Does art have an origin and adaptive function? In K. Zijlmans \& W. van Damme (eds.), World art studies: Exploring concepts and approaches (pp. 241-263). Amsterdam: Valiz.
}

[6] Coomaraswamy, Ananda K. Why exhibit works of art? Source: Studies in comparative religion, Vol 5, No. 3 (summer, 1971). World wisdom, Inc.

[7] Daniel Gurnon, Julian Voss-Andreae, and Jacob Stanley, Integrating Art and Science in Undergraduate Education, PLoS Biol. Feb 2013; 11(2): e1001491.

[8] Das, 1900, The science of the emotions, London and benares theosophical publishing society.

[9] Dasgupta S. N., 1960, Fundamentals of Indian Art, Bhavan's Book University, Bombay, India

[10] Davar F. C., 1935, Art and morality and other essays, D. B. Taraporevala sons \& co. Bombay.

[11] De Bono, Edward, Serious creativity, The journal for quality and participation; Sep 1995; 18, 5; ABI/INFORM Global pg. $12-18$

[12] Dine, Susan, 2012, Sanskrit Beyond Text: The Use of Bonji (Siddham) in Mandala and Other Imagery in Ancient and Medieval Japan, University of Washington.

https:/digital.lib.washington.edu/researchworks/bitstream/ha ndle/1773/20584/Dine washington 0250O 10572.pdf?sequ ence $=1$

[13] Dissanayake, e. (2003). "Core of Art: Making Special." Journal of the Canadian Association of Curriculum Studies volume1, number 2.

[14] Dissanayake, e. (2008). The arts after Darwin: Does art have an origin and adaptive function? In K. Zijlmans \& W. van Damme (eds.), World art studies: Exploring concepts and approaches (pp. 241-263). Amsterdam: Valiz.

[15] Eastlake, Lady, 1874, Hand book of painting, John Murray, London.

[16] Edward A. Vesse, G. Gabrielle Starr, and Nava Rubin, Art reaches within: aesthetic experience, the self and the default mode network, Front Neurosci. 2013; 7: 258.

[17] Elgood, Heather, 1999, Hinduism and the Religious Arts, Cassell Wellington House, London.

[18] Geist, Richard, Empathy, connectedness and the evolution of boundaries in self-psychological treatment, International Journal of Psychoanalytic Self Psychology, 2009, 4: 165-180

[19] Getlein (9th Ed) (2010), Living with Art, New York, Mc Graw Hill Companies, Inc.

[20] Goertzel, Ben, CHAOTIC LOGIC: Language, Mind and Reality from the Perspective of Complex Systems Science, Plenum Press, New York and London.

[21] http://arttherapywithoutborders.wordpress.com/

[22] http://psychcentral.com/blog/archives/2011/01/13/5-ideas-fo r-cultivating-a-sense-of-wonder/

[23] http://psychology.about.com/od/sigmundfreud/tp/facts-about -freud.htm

[24] http://www.learningayurveda.com/2012/08/31/ashtanga-hrud aya-sutra-sthana-chapter-1-basic-principles-of-ayurveda/

[25] http://www.leeds.ac.uk/educol/documents/156298.htm

[26] http://www.theartstory.org/artist-de-chirico-giorgio.htm 
[27] http://www.toptenz.net/top-10-tortured-artists.php

[28] https://www.apa.org/monitor/2011/11/suicide.aspx

[29] Iyer K. Bharatha, 1958, Indian Art a short introduction, Asia Publishing House, India.

[30] J. S. Mausner and R. C. Steppacher, Suicide in professionals: A study of male and female psychologists, http://aje.oxfordjournals.org/content/98/6/436

[31] Jasani SK, Saks NS. Utilizing visual art to enhance the clinical observation skills of medical students. Med Teach. 2013 Jul;35(7):e1327-31.

[32] Jo Marie Reilly; Jeffrey Ring; Linda Duke. Visual Thinking Strategies: A New Role for Art in Medical Education, Fam Med 2005; 37(4): 250-2.

[33] Kalmanowitz, Potash, \& Chan, (2012), Art therapy in Asia: To the bone or wrapped in silk, London \& Philadelphia, Jessica Kingsley Publishers.

[34] Kaplan (2000), Art, Science and Art Therapy: Repainting the Picture, London and Philadelphia, Jessica Kingsley Publishers.

[35] Kowalski, Robert, The limitations of logic, http://www.doc.ic.ac.uk/ rak/papers/limitations $\% 20$ of $\% 201$ o gic.pdf

[36] Kramarisch S, (1928), Vishnudharmottara, Calcutta University Press.

[37] Lankston., Cusack., Fremantle., Isles, Visual art in hospitals: case studies and review of the evidence, J R Soc Med. Dec 1, 2010; 103(12): 490-499

[38] Lehrer, Keith, 2011, Art, Self and Knowledge, Oxford University Press, Inc., New York

[39] Malchiodi, (2003), Hand book of Art Therapy, New York, London, The Guilford Press.

[40] Mausner, J. S. and Steppatcher, R. C. 1973. Suicide in professionals: A study of male and female psychologists, American Journal of Epidemiology. 98: 436-445.

[41] McNiff, Shaun 1992, Art as medicine: creating a therapy of the imagination, Shambhala, Massachusetts.

[42] Monti, Peterson, Kunkel, Hauck, Pequignot, Rhodes and Brainard, A randomized, controlled trial of mindfulness-based art therapy (MBAT) for women with cancer, Psycho-Oncology 15: 363-373 (2006)

[43] Moon L. Bruce, 2009, Existential Art Therapy: The Canvas Mirror, Charles C Thomas Publisher, Illinois.

[44] Nucho, Aina O, (2003), The psychocybernetic model of art therapy, Illinois, CHARLES C THOMAS PUBLISHER,
LTD.

[45] Philip Sherrard, Art and Originality, Source: Studies in Comparative Religion, Vol. 14, Nos. 3 \& 4. (Summer-Autumn, 1980). World Wisdom, Inc.

[46] Reynolds., Kamphaus. 2003, Handbook Of Psychological And Educational Assessment Of Children Intelligence, Aptitude, and Achievement, THE GUILFORD PRESS, New York and London.

[47] Rubin, J.A. (1978). Child Art Therapy, New York: John Wiley \& Sons, 2nd Ed. 1984, 3rd Ed., 2005.

[48] Santora., Dowell., Henningfield, 2010, Addiction and Art, The Johns Hopkins University Press, Baltimore

[49] Schultz, P. D., Schultz, E. S. (8th Ed) (2005), Theories of personality, Belmont, Wadsworth.

[50] Simon Lacey., Henrik Hagtvedt., Vanessa M. Patrick., Amy Anderson., Randall Stilla., Gopikrishna Deshpande., Xiaoping Hu., João R. Sato., Srinivas Reddy., and K. Sathian, Art for reward's sake: Visual art recruits the ventral striatum. Neuroimage. Mar 1, 2011; 55(1): 420-433.

[51] Solso, 1997, Cognition and the visual arts, MIT Press, Cambridge.

[52] Staricoff research report. http://www.artsandhealth.ie/wp-content/uploads/2011/08/A HReview-of-Medical-Literature1.pdf

[53] Strack, 2005, Handbook of personology and psychopathology, John Wiley \& Sons, Inc., New Jersey.

[54] Studies show that incorporating the arts can save money, improve the patient experience - and do a lot more. http://www.ucira.ucsb.edu/why-we-need-the-arts-in-medicin e/

[55] Wright (2010), Understanding Creativity in Early Childhood, London, Sage Publications Ltd.

[56] Zabelina., Robinson, Child's Play: Facilitating the Originality of Creative Output by a Priming Manipulation, Psychology of Aesthetics, Creativity, and the Arts, 2010, Vol. 4, No. 1, 57-65

[57] Zeki, 1999. Art and the brain. Journal of Consciousness Studies, 6(6-7), 76-96.

[58] Zeki, 2000, Inner vision: an exploration of art and the brain, Oxford University Press, New York

[59] Zeki, a former professor of neurobiology at the University College, London published an article, "Artistic Creativity and the Brain," in Science Magazine, in July 2001. 